\title{
Inserção da Temática Ambiental em um Curso de Licenciatura em Ciências Biológicas: Concepções dos Docentes e Suas Práticas Pedagógicas
}

\author{
Insertion of the Environmental Theme in a Bachelor's Degree Coursen in Biological \\ Sciences: Professors' Conceptions and Their Pedagogical Practices
}

\author{
Inserción del Tema Ambiental en un Curso de Grado de Bachillerato en Ciencias \\ Biológicas: Las Concepciones de los Maestros y Sus Prácticas Pedagógicas
}

\author{
Glória Cristina Marques Coelho Miyazawa ${ }^{1}$ \\ Rita de Cássia Frenedozo ${ }^{2}$ \\ Rui Marques Vieira ${ }^{3}$
}

\begin{abstract}
Resumo
Este artigo apresenta um trabalho de investigação focado na análise da inserção da temática ambiental em um curso de Ciências Biológicas de uma instituição federal, partindo da percepção da coordenadora e dos docentes. A pesquisa é qualitativa, utilizando entrevistas semiestruturadas como instrumento de coleta de dados e análise de conteúdo, para a interpretação dos resultados. A maioria dos docentes mostrou uma concepção de meio ambiente antropocêntrica e de educação ambiental, com finalidade de conscientização ou mudança de atitudes. Os docentes relataram que inserem a temática ambiental nas práticas das suas disciplinas, mas na maioria delas de forma esporádica. Não há diálogo entre os docentes para organizar o modo de inserção, ficando sob a responsabilidade de cada um definir como isso se dará na sua disciplina. Os resultados indicam que a temática está inserida no curso, mas que a formação continuada dos docentes e uma maior integração das disciplinas poderiam aprimorar ainda mais esse trabalho.
\end{abstract}

Palavras-chave: Formação inicial de professores. Temática ambiental. Concepção de docentes do ensino superior. Práticas pedagógicas.

\begin{abstract}
This article presents a research work focused on the analysis of the insertion of the environmental theme in a Biological Sciences course of a federal institution, starting from the perception of the coordinator and professors. The research is qualitative, using semi-structured interviews as an instrument of data collection and content analysis for the interpretation of the results. Most professors showed an anthropocentric conception of environment and environmental education, with the purpose of consciousness-raising or changing attitudes. The professors reported that they insert the environmental theme in the practices of their disciplines, but mostly sporadically. There is no dialogue between professors to organize the method of insertion, being under the responsibility of each one to define how this will be done in their discipline. The results indicate that the theme is inserted in the course, but the continued formation of the professors and a greater integration of disciplines could further improve this work.
\end{abstract}

Keywords: Teacher training. Environmental theme. Conception of higher education professors. Pedagogical practices.

\section{Resumen}

Este artículo presenta un trabajo de investigación centrado en el análisis de la inserción del tema ambiental en un curso de Ciencias Biológicas de una institución federal, a partir de la percepción del coordinador y los docentes.

\footnotetext{
${ }^{1}$ Doutora em Ensino de Ciências e Matemática. Docente do Instituto Federal de Educação, Ciência e Tecnologia de São Paulo - Câmpus São Roque, Brasil. E-mail: gmiyazawa @ifsp.edu.br

${ }^{2}$ Doutora em Geociências e Meio Ambiente. Docente da Universidade Cruzeiro do Sul, Brasil. E-mail: ritafrenedozo@yahoo.com.br

${ }^{3}$ Doutor em Didática. Docente do Departamento de Educação e Psicologia da Universidade de Aveiro, Portugal. E-mail: rvieira@ua.pt
} 
La investigación es cualitativa, utilizando entrevistas semiestructuradas como instrumento de recolección de datos y análisis de contenido para la interpretación de los resultados. La mayoría de los docentes mostraron una concepción antropocéntrica del medio ambiente y la educación ambiental, con el objetivo de crear conciencia o cambiar las actitudes. Los docentes informaron que insertan el tema ambiental en las prácticas de sus disciplinas, pero esporádicamente, en su mayoría. No hay diálogo entre los profesores para organizar el método de inserción, así que la responsabilidad para definirlo en la disciplina es individual. Los resultados indican que la temática se inserta en el curso, pero la formación continua de los docentes y una mayor integración de las disciplinas podrían mejorar aún más este trabajo.

Palabras-clave: Formación inicial de profesores. Temática ambiental. Concepción de docentes de la enseñanza superior. Prácticas pedagógicas.

\section{Introdução}

O cenário mundial apresenta graves e complexos problemas ambientais decorrentes de uma irracionalidade na produção e consumo, que considera o meio natural como mercadoria para atender às exigências do mercado, levando à desigualdade e exclusão. Diante da grave crise existente, é urgente inserir essa dimensão no meio educacional, mas de modo que se comprometa com os processos de transformação das relações de dominação e de exploração, de opressor e oprimido (GUIMARÃES; QUEIROZ; PLÁCIDO, 2014).

A educação ambiental (EA) deve ser vista como um processo fundamental na busca de soluções para os problemas ambientais, analisando suas causas e consequências; visando superar a visão reducionista e a relação equivocada existente entre os seres humanos e seu ambiente (GUIMARÃES; INFORSATO, 2010). Ela não pode ser restrita ao aspecto ecológico, mas associada a uma visão contextualizada da realidade, envolvendo também os aspectos sociais, econômicos, políticos, éticos e culturais (FRAZÃO; SILVA; CASTRO, 2010).

A Política Nacional de Educação Ambiental (PNEA) - Lei no 9795/1999 (BRASIL, 1999) - estabelece algumas diretrizes em seus princípios e objetivos que orientam a operacionalização da educação ambiental no ambiente escolar, como a complexidade da questão ambiental, as interações entre ambiente, cultura e sociedade e o caráter crítico, político, interdisciplinar, contínuo e permanente (LIPAI; LAYRARGUES; PEDRO, 2007). Para se trabalhar a educação ambiental nas escolas, de forma comprometida com a realidade ambiental, é essencial que esse processo se dê também e exemplarmente nas instituições de ensino superior, particularmente dentro dos cursos de formação inicial e continuada de professores.

A universidade tem papel fundamental na inserção e sistematização da dimensão ambiental no currículo de seus cursos, principalmente de licenciatura e deve formar professores que articulem o saber pedagógico e o ambiental, combinando a reflexão e a prática para promover a formação de cidadãos reflexivos e ativos, capazes de analisar e se colocar criticamente frente à ordem social em que vivem, contribuindo para a estruturação de uma sociedade mais justa, mais humana e ambientalmente sustentável (RODRIGUES; OLIVEIRA; QUEIROZ, 2013).

Para Pavesi (2012, p. 156), o desafio da instituição e dos docentes na inserção da temática ambiental

consistiria menos em sistematizar e transmitir aos alunos definições, conhecimentos e soluções prontas para os problemas ambientais e mais em criar oportunidades e percursos didáticos que incorporem os princípios metodológicos da pesquisa e, ao mesmo tempo, estimulem os alunos a avaliar os resultados socioambientais de suas decisões e ações. 
Souza (2016) defende que as ações ambientais desenvolvidas dentro das instituições de ensino superior ocorrem de forma pontual, estando pouco presente na rotina acadêmica e mobilizando um número reduzido de pessoas, o que impossibilita a ocorrência de mudanças significativas diante da crise ambiental. As oportunidades de reflexão que se oferece sobre as diferentes concepções de relação homem-natureza e de educação são poucas e superficiais (TOZONI-REIS, 2001).

A universidade precisa modificar seu ensino para que os profissionais possam ir além do senso comum, compreendendo, analisando, refletindo, participando e intervindo na problematização e soluções dos problemas ambientais (MORALES, 2010).

A partir da revisão de literatura realizada por Juliani, Santos, Garcia e Rezende-Filho (2014) de como a EA vem sendo inserida nos currículos dos cursos de formação de professores de Ciências, encontrou-se duas modalidades diferentes: existência de um componente curricular específico de EA e sua inserção em disciplinas que tratam do tema, mas não de forma central. Além desses, outra forma de inserção citada por Di Tullio e Oliveira (2017) é através de atividades extracurriculares isoladas resultantes do esforço pessoal de docentes comprometidos.

No projeto pedagógico do curso de Licenciatura em Ciências Biológicas (LCB) de uma instituição federal brasileira, objeto de estudo desta pesquisa, a temática ambiental está presente no plano de ensino da maioria das disciplinas do curso em virtude da exigência de diretrizes institucionais da Pró-Reitoria de Ensino (PRE), estabelecidas pela obrigatoriedade legal presente em dois documentos: i) artigo 11 da PNEA, que estabelece "A dimensão ambiental deve constar dos currículos de formação de professores em todos os níveis e em todas as disciplinas" (BRASIL, 1999); ii) item 13 do instrumento de avaliação dos cursos de graduação presencial e a distância do Inep/Daes/Sinaes (BRASIL, 2012) que, no processo de reconhecimento do curso, avaliam se há integração da educação ambiental nas disciplinas do curso de modo transversal, contínuo e permanente. Diante disso, surgiu o interesse em investigar se essa exigência gerou mudanças nas atividades acadêmicas do curso, inserindo de forma concreta a temática ambiental.

Pela relevância do tema e o fato de não ter sido encontrado na literatura nenhuma outra pesquisa feita com um curso que apresenta tal especificidade, defende-se que esta investigação possa gerar conhecimento para subsidiar outros estudos, reflexões e pesquisas sobre a inserção da temática ambiental na formação inicial de professores.

A pesquisa torna-se ainda mais relevante se considerarmos a importância do curso de LCB como instância formadora de professores que atuarão em EA, visto que muitos estudos apontam que a inserção da educação ambiental na escola básica fica por conta dos professores de Ciências, Biologia e Geografia (GUIMARÃES, 2005; TOZONI-REIS; CAMPOS, 2014; TRISTÃO, 2002) pela afinidade dos conteúdos em relação à temática ambiental, embora a abordagem deva ser feita de forma transversal, por todas as disciplinas.

Nesse contexto, este artigo apresenta a inserção da temática ambiental no curso de LCB considerando a visão dos docentes, com base nas seguintes questões de pesquisa: Como os docentes do curso de LCB concebem meio ambiente e educação ambiental? Eles inserem a temática ambiental nas suas disciplinas? De que forma a consideram? Quais os limites e potencialidades apontadas pelos docentes para inserir a temática ambiental dentro do curso? Os objetivos que guiaram esta investigação foram identificar as concepções de meio ambiente e educação ambiental dos docentes do curso, bem como analisar de que modo referem incorporar a temática ambiental em suas práticas pedagógicas e a partir disso refletir sobre a inserção da temática na formação inicial de professores.

\section{Inserção da temática ambiental na formação inicial de professores}


A inserção da temática ambiental nos cursos de formação inicial de professores é hoje uma exigência, visto que são os mediadores dos processos educativos formais dentro da escola, precisando ter o entendimento da EA como uma "prática educativa que procura articular os aspectos políticos, sociais, econômicos e ambientais no processo de formação dos sujeitos-cidadãos" (OLIVEIRA; CARVALHO, 2012, p. 253). Durante a formação inicial, os futuros professores devem ter contato com ações pedagógicas que problematizem e questionem a estrutura capitalista, exploratória e conservadora da nossa sociedade para colocarem em prática uma EA emancipatória e crítica (UNTALER; BAROLLI, 2010), que seja "comprometida com a superação de relações socioambientais desiguais, percebendo a educação como forma de intervenção no mundo" (FREIRE; FIGUEIREDO; GUIMARÃES, 2016, p. 118).

É preciso pensar com urgência na formação do educador ambiental, pois ele é um importante agente no enfrentamento da problemática ambiental e deve ter capacidade de ler a complexidade do mundo e se comprometer com a transformação responsável da realidade, tão marcada por desigualdades. As práticas educativas articuladas com a problemática ambiental devem ser consideradas

como parte componente de um processo educativo que reforce um pensar da educação orientado para refletir a educação ambiental num contexto de crise ambiental, de crescente insegurança e incerteza face aos riscos produzidos pela sociedade global, o que, em síntese, pode ser resumido como uma crise civilizatória de um modelo de sociedade (JACOBI, 2005, p. 243).

Nesse sentido, a formação de professores críticos, reflexivos, com uma postura interdisciplinar, construtivista e comunicacional precisa estar associada a uma nova concepção de escola, preocupada com a construção de uma sociedade melhor para se viver, em que o professor, através da reflexão-ação, reconstrua sua prática ao mesmo tempo em que ajude a reconstruir a escola e a realidade ambiental à sua volta (SANTOS; JACOBI, 2011). Para que a inserção da educação ambiental nas escolas supere as fragilidades com que tem sido incorporada, a formação dos futuros professores não pode ocorrer de maneira isolada, fragmentada e incipiente; ela precisa ser sólida para que compreendam e enfrentem a complexidade, alicerçada na reflexão, na prática e na prática reflexiva, a partir dos conceitos de reflexão na ação, sobre a ação e de reflexão sobre a reflexão na ação (TOZONI-REIS; CAMPOS, 2015).

O professor, para agir sob a égide da EA, deve adquirir na sua formação inicial conteúdos teóricos, procedimentais e atitudinais que possibilitem compreender as questões ambientais para além de suas dimensões biológicas, químicas e físicas; o que exige a interação entre o conhecimento específico disciplinar, a formação pedagógica e a formação ambiental, através de um campo de conhecimentos teóricos e práticos orientados para a rearticulação das relações sociedade/natureza que o prepare para uma ação contextualizada, em que consiga acompanhar, entender e discutir as relações e o dinamismo que regem o ambiente (ARAÚJO, 2004).

Inúmeros estudos no Brasil e no mundo vêm investigando a inserção da temática ambiental nos cursos de formação inicial de professores, com base principalmente na pesquisa documental dos projetos pedagógicos dos cursos ou entrevistas com discentes (CORTES JUNIOR; FERNANDEZ, 2016; DINIZ; CHAGAS, 2014; LOPES; ZANCUL, 2012; MODESTO; ARAÚJO, 2015; MOITA NETO; SANTOS, 2011; TEIXEIRA; TORALES, 2014). Um número menor de publicações tem como foco os docentes universitários formadores de professores e geralmente restringem-se àqueles que atuam em disciplinas que abordam a temática ambiental (GUERRA et al., 2014; PITANGA; NEPOMUCENO; 
ARAÚJO, 2017; ROLOFF; MARQUES, 2014; ROSALEM; BAROLLI, 2010; SILVA; TEIXEIRA, 2015; THOMAZ; CAMARGO, 2007; dentre outros). Não foi encontrada nenhuma pesquisa que considerou todos os docentes de um curso de licenciatura como este estudo, o que provavelmente se deve ao fato de nenhum outro curso ter a temática ambiental inserida na maioria das disciplinas como este. Conhecer as concepções e práticas do corpo docente é essencial para avaliar se estão preparados para inserir a temática ambiental na formação inicial de professores de forma crítica, atendendo aos pressupostos enunciados acima.

\section{Procedimentos metodológicos}

Este artigo apresenta um recorte da pesquisa de Doutorado da primeira autora deste trabalho, a qual consiste em um estudo de caso focado na inserção da temática ambiental no curso de LCB de uma instituição federal brasileira, analisando a dimensão ensino, pesquisa e extensão, aprovado pelo Comitê de Ética em Pesquisa da universidade com o número de protocolo 0162016. Aqui sistematizamos e discutimos os dados relativos à análise dessa inserção, partindo da percepção dos agentes centrais desse processo, da coordenadora e dos docentes do curso.

Como instrumento de coleta de dados utilizou-se entrevistas semiestruturadas, com questões abertas, aplicadas à coordenadora do curso e aos 24 docentes que ministraram as disciplinas no ano de 2016. A opção por questões abertas se deu com o intuito de possibilitar aos docentes discorrerem livremente sobre cada um dos aspectos abordados, e constituir um momento de diálogo entre entrevistadora e entrevistado, sendo possível complementar respostas a questões anteriores no decorrer da entrevista. A autorização dos docentes se deu pela assinatura do Termo de Consentimento Livre e Esclarecido e eles estão identificados neste artigo por nomes de animais e plantas da Mata Atlântica, sem indicação das disciplinas que ministram, para preservar a identidade deles. As entrevistas foram gravadas utilizando o software Gravador de Som ${ }^{\circledR}$ e posteriormente transcritas, com auxílio do software InqScribe®.

As entrevistas foram compostas por duas partes. A primeira parte continha questões de identificação do sujeito e caracterização do seu perfil no tocante à faixa etária; formação acadêmica (graduação, mestrado, doutorado); disciplina(s) que leciona no curso; a inserção da temática ambiental na sua graduação e experiência profissional; conhecimento da Política Nacional de Educação Ambiental - Lei no 9795/99. A segunda parte da entrevista foi composta por cinco eixos temáticos: 1. aspectos conceituais (concepção de meio ambiente e educação ambiental); 2. inserção da temática ambiental na formação inicial de professores; 3 . práticas pedagógicas; 4. interdisciplinaridade e transversalidade; e 5. limites e potencialidades à inserção da temática ambiental.

O roteiro da entrevista foi validado por quatro docentes de cursos de LCB de outras instituições públicas de ensino, doutores que analisaram a adequação do formato e conteúdo das questões. A avaliação deles foi positiva, favorável à permanência de todas as questões, com sugestão de pequenos ajustes que foram incorporados ao instrumento.

$\mathrm{Na}$ interpretação dos resultados utilizou-se análise de conteúdo (BARDIN, 1977, 2011), com o auxílio do software webQDA® (Web Qualitative Data Analysis). De acordo com Bilert (2014, p. 1156), "a análise do conteúdo permite o recorte das mensagens de acordo com expressões e temas que tenham interação com os objetivos da pesquisa e percepção do pesquisador, seja nas expressões, contradições e, até, nas repetições das mensagens". Considerando a riqueza e expressividade dos relatos dos docentes, destaca-se neste trabalho 
os excertos mais significativos, já que a limitação do tamanho do artigo não comportaria toda a gama de informações obtidas.

As concepções dos docentes sobre meio ambiente e educação ambiental foram identificadas, com definição de categorias à posteriori, baseadas em uma ampla revisão de literatura com destaque para Sauvé (2005a, 2005b). A validação das concepções foi de caráter qualitativo, realizada por duas especialistas da área, através de um exercício de codificação de 49 unidades de texto. Não houve consenso nas codificações de sete unidades de texto e após uma reavaliação, assumimos a codificação das especialistas em três unidades de análise.

\section{Resultados}

\subsection{Caracterização dos docentes}

A análise da primeira parte da entrevista mostra a identidade dos docentes que atuam no curso de LCB investigado. Os docentes têm formação inicial variada, com um maior número em Ciências Biológicas e outros da área de Agronomia, Letras, Matemática, Pedagogia, Química, Ciências da Computação, Ciências Sociais, Física, Tecnologia em Viticultura e Enologia. A maioria encontra-se em uma faixa etária entre 31 e 50 anos, com mestrado ou doutorado (Tabela 1).

Tabela 1 - Perfil dos docentes do curso de Licenciatura em Ciências Biológicas.

\begin{tabular}{|c|c|c|c|c|c|c|c|c|c|c|c|}
\hline \multirow[b]{2}{*}{ Graduação } & \multicolumn{2}{|c|}{ Sexo } & \multicolumn{5}{|c|}{ Idade (anos) } & \multicolumn{3}{|c|}{ Grau Acadêmico } & \multirow[b]{2}{*}{$\begin{array}{l}\text { TOT } \\
\text { AL }\end{array}$} \\
\hline & $\begin{array}{c}\text { Fem } \\
\text { inin } \\
0\end{array}$ & $\begin{array}{l}\text { Mas } \\
\text { culin } \\
0\end{array}$ & $\begin{array}{c}20 \\
- \\
30\end{array}$ & $\begin{array}{l}31- \\
40\end{array}$ & $\begin{array}{l}41- \\
50\end{array}$ & $\begin{array}{l}51- \\
60\end{array}$ & $\begin{array}{l}\text { Ma } \\
\text { is } \\
\text { de } \\
60\end{array}$ & $\begin{array}{l}\text { Espe } \\
\text { cializ } \\
\text { ação }\end{array}$ & $\begin{array}{c}\text { Mes } \\
\text { trad } \\
0\end{array}$ & $\begin{array}{c}\text { Do } \\
\text { uto } \\
\text { rad } \\
\text { o }\end{array}$ & \\
\hline Ciências Biológicas & 1 & 7 & 0 & 2 & 5 & 1 & 0 & 0 & 3 & 5 & 8 \\
\hline Agronomia & 0 & 3 & 0 & 3 & 0 & 0 & 0 & 0 & 1 & 2 & 3 \\
\hline Letras & 1 & 2 & 1 & 2 & 0 & 0 & 0 & 1 & 0 & 2 & 3 \\
\hline Matemática & 2 & 0 & 0 & 1 & 0 & 1 & 0 & 0 & 1 & 1 & 2 \\
\hline Pedagogia & 1 & 1 & 0 & 0 & 1 & 0 & 1 & 0 & 1 & 1 & 2 \\
\hline Química & 1 & 1 & 1 & 0 & 1 & 0 & 0 & 0 & 2 & 0 & 2 \\
\hline $\begin{array}{l}\text { Ciências da } \\
\text { Computação }\end{array}$ & 0 & 1 & 0 & 0 & 1 & 0 & 0 & 1 & 0 & 0 & 1 \\
\hline Ciências Sociais & 0 & 1 & 0 & 1 & 0 & 0 & 0 & 0 & 0 & 1 & 1 \\
\hline Física & 0 & 1 & 0 & 1 & 0 & 0 & 0 & 0 & 0 & 1 & 1 \\
\hline $\begin{array}{l}\text { Tecnologia em } \\
\text { Viticultura e } \\
\text { Enologia }\end{array}$ & 0 & 1 & 0 & 1 & 0 & 0 & 0 & 0 & 0 & 1 & 1 \\
\hline TOTAL & 6 & 18 & 2 & 10 & 9 & 2 & 1 & 2 & 8 & 14 & 24 \\
\hline
\end{tabular}

De acordo com o relato dos docentes formados em Ciências Biológicas, a abordagem da temática ambiental na formação inicial deles ocorreu nas disciplinas obrigatórias de Ecologia, Botânica, Botânica Econômica e Zoologia, sendo que apenas dois informaram ter tido uma disciplina específica de educação ambiental, na qual um deles enfatizou ter tido uma grande quantidade de aulas de campo. Para os docentes das outras áreas, a temática ambiental não foi contemplada na formação inicial para sete docentes; um deles teve como disciplina obrigatória; três como disciplina optativa em que o docente escolheu fazer e cinco tiveram de 
forma esporádica, com algumas aulas dentro de uma disciplina ou através de palestra. Nenhum docente do curso teve na formação inicial a abordagem da temática ambiental através do desenvolvimento de projetos ou de forma interdisciplinar.

Dos 24 docentes, 19 deles informaram ter tido algum contato com a temática ambiental na sua experiência profissional, sendo a maioria (16) dentro de escolas atuando como professor (12), diretor (2), coordenador formador de professores (2) ou desenvolvendo projetos interdisciplinares (3); 5 docentes tiveram experiência na área técnica, trabalhando em empresas, instituições de pesquisa, reserva particular e órgãos públicos. Dois docentes enfatizaram que a temática ambiental teve influência muito grande na sua experiência pessoal e 3 informaram nunca ter trabalhado com a temática ambiental.

Em relação à Política Nacional de Meio Ambiente, a menor parte dos docentes (6) disseram conhecer bem, enquanto 9 disseram conhecer de forma superficial e 9 não a conhecem.

\subsection{Concepção de meio ambiente e educação ambiental}

O conhecimento das concepções que os docentes apresentam em relação aos conceitos de meio ambiente e educação ambiental é necessário para verificar a influência disso nas práticas pedagógicas deles, considerando que desenvolverão o ensino de forma coerente com a maneira como o compreende.

As categorias definidas para a concepção de meio ambiente foram: naturalista, antropocêntrica e não elucidativa (Quadro 1) e para educação ambiental foram: conscientização, mudança de atitudes, científica, crítica, para o desenvolvimento sustentável, e não elucidativa (Quadro 2).

Quadro 1 - Descrição das concepções de meio ambiente

\begin{tabular}{|c|c|l|}
\hline Categoria & $\begin{array}{l}\text { Dimensões } \\
\text { de análise }\end{array}$ & \multicolumn{1}{c|}{ Indicadores } \\
\hline $\begin{array}{c}\text { Concepção } \\
\text { ambiental }\end{array}$ & $\begin{array}{c}\text { Meio } \\
\text { ambiente }\end{array}$ & $\begin{array}{l}\text { Naturalista - concepção evidenciando somente aspectos naturais, } \\
\text { não incluindo o ser humano. Muitas vezes citam termos como } \\
\text { natureza, bióticos, abióticos, biodiversidade, ecologia. }\end{array}$ \\
& $\begin{array}{l}\text { Antropocêntrica - concepção que inclui o ser humano, ou o que o } \\
\text { cerca. O ambiente como um lugar que contém formas de vida e } \\
\text { pessoas; o ambiente que faz coisas pelas pessoas; as pessoas são parte } \\
\text { do ambiente e são responsáveis por ele; e as pessoas e o ambiente } \\
\text { interagem entre si. }\end{array}$ \\
\cline { 2 - 2 } & $\begin{array}{l}\text { Não elucidativa: não apresenta uma concepção clara ou confunde } \\
\text { meio ambiente e educação ambiental, em que meio ambiente não é } \\
\text { visto como um espaço onde se vive e sim como uma ação educativa. }\end{array}$ \\
\hline
\end{tabular}

Quadro 2 - Descrição das concepções de educação ambiental (EA)

\begin{tabular}{|c|c|c|c|}
\hline Categoria & $\begin{array}{l}\text { Dimensões } \\
\text { de análise }\end{array}$ & \multicolumn{2}{|c|}{ Indicadores } \\
\hline $\begin{array}{c}\text { Concepção } \\
\text { ambiental }\end{array}$ & $\begin{array}{l}\text { Educação } \\
\text { ambiental }\end{array}$ & $\begin{array}{l}\text { Conscientização: concepção de EA com caráter de aquisição ou } \\
\text { transmissão de conhecimento a respeito do ambiente, sua } \\
\text { importância, como "preservar" e/ou "conservar". }\end{array}$ \\
\hline
\end{tabular}




\begin{tabular}{|l|l|}
\hline \multirow{2}{|l|}{} & $\begin{array}{l}\text { Mudança de atitudes: concepção de EA como formação para } \\
\text { desenvolver comportamentos mais adequados em relação ao } \\
\text { ambiente. }\end{array}$ \\
\hline $\begin{array}{l}\text { Científica: concepção de EA associada à aquisição de conhecimentos } \\
\text { técnicos para escolher uma solução ou ação apropriada em relação ao } \\
\text { ambiente. }\end{array}$ \\
\hline $\begin{array}{l}\text { Crítica: concepção de EA mais integradora, reflexiva, que considera } \\
\text { a complexidade da relação ser humano-natureza, o modelo } \\
\text { econômico atual e a dimensão política. }\end{array}$ \\
\hline $\begin{array}{l}\text { Desenvolvimento sustentável: concepção de Educação Ambiental } \\
\text { como forma de aprender a utilizar racionalmente os recursos naturais, } \\
\text { pensando na sustentabilidade. }\end{array}$ \\
\hline $\begin{array}{l}\text { Não elucidativa: não traz uma concepção, mas expressa uma } \\
\text { discussão em torno da problemática ou se refere a EA como } \\
\text { disciplina. }\end{array}$ \\
\hline
\end{tabular}

Uma concepção naturalista de meio ambiente foi apresentada por cinco docentes, destacando apenas elementos naturais, como por exemplo: "Meio ambiente é tudo relacionado com a questão da natureza, do ambiente, da natureza, a questão ecológica mesma" (Manacá); "Meio ambiente é o local onde você encontra a biodiversidade e a associação entre os organismos que estão ali e o ambiente em que eles vivem" (Guapuruvu).

A maioria dos docentes mostrou uma concepção de meio ambiente antropocêntrica (16), relacionando ao espaço onde o ser humano vive. Dentro dessa concepção, houve docente que embora tenha incluído o ser humano, destacou apenas aspectos naturais: "Meio ambiente são todos os fatores físicos e biológicos que estão em volta da gente" (Pau-brasil), "Meio ambiente é amplo, envolve natureza, que a gente costuma colocar fora da gente, floresta, biomas, animais, seres humanos, ar que nos cerca" (Ipê); outro incluiu também o aspecto cultural:

Eu entendo meio ambiente como sendo a interação entre o vivo e o não vivo, mas eu enalteço muito a questão cultural; então eu acho que assim é essa relação do biótico com o abiótico, do homem com a natureza, envolvendo os seus aspectos históricos e culturais, que eu acho muito importante (Papagaio).

$\mathrm{Na}$ concepção de educação ambiental, houve predomínio das categorias conscientização (8) e mudança de atitudes (7). A concepção crítica foi atribuída por apenas dois docentes, que destacaram os aspectos social e econômico e a reflexão (Figueira); e os aspectos social e político (Sagui), mostrando considerar a abrangência e complexidade da temática. Esses resultados podem ser indicativos de uma possível visão fragmentada da temática socioambiental pelos docentes. O Quadro 3 apresenta excertos representativos de cada uma dessas concepções. Não houve relação direta entre a formação inicial e titulação acadêmica dos docentes com as concepções apresentadas.

Quadro 3 - Concepções de educação ambiental apresentadas por alguns docentes

\begin{tabular}{|l|l|}
\hline \multicolumn{1}{|c|}{ Indicadores } & \multicolumn{1}{c|}{ Excertos } \\
\hline Educação ambiental & "Educação ambiental é uma forma de conscientizar as pessoas da \\
para & importância dessa questão de meio ambiente, de preservação do \\
conscientização & meio ambiente e de tudo que envolve ele" (Bugio). \\
\cline { 2 - 2 } & "Conscientização pessoal e coletiva da importância do ambiente, dos \\
& valores e da nossa interação com ele" (Embaúba). \\
\hline
\end{tabular}




\begin{tabular}{|c|c|}
\hline & $\begin{array}{l}\text { "Coloco como a própria conscientização do ambiente, do meio } \\
\text { ambiente, da biodiversidade contida nele para a percepção e a } \\
\text { conservação do mesmo" (Guapuruvu). }\end{array}$ \\
\hline \multirow[t]{2}{*}{$\begin{array}{l}\text { Educação ambiental } \\
\text { para mudança de } \\
\text { atitudes }\end{array}$} & $\begin{array}{l}\text { "Educação ambiental é como você se relacionar com esse ambiente } \\
\text { de forma (ficou pensando) adequada, civilizada, não é bem o termo } \\
\text { mas não estou lembrando o termo correto" (Manacá). }\end{array}$ \\
\hline & $\begin{array}{l}\text { "O conceito em si seria de certa maneira uma forma de educar ou de } \\
\text { certa maneira verificar quais são as 'boas maneiras' em se tratar com } \\
\text { esse meio ambiente, a fim de preservá-lo da mesma forma como ele } \\
\text { foi concebido" (Teiú). }\end{array}$ \\
\hline $\begin{array}{l}\text { Educação ambiental } \\
\text { crítica }\end{array}$ & $\begin{array}{l}\text { "Eu nunca pensei nisso mas acho que é a Educação que traz para o } \\
\text { aluno a percepção de tudo o que está relacionado com a sua vivência } \\
\text { biológica e social, de todos os elementos que atuam, que contribuem, } \\
\text { que participam desse desenvolvimento humano em uma dimensão } \\
\text { bastante ampla, então pensando a parte biológica, a parte social, } \\
\text { enfim, todas as dimensões da vida humana, até mesmo político, por } \\
\text { que não?" (Sagui). }\end{array}$ \\
\hline
\end{tabular}

\subsection{Inserção da temática ambiental na formação inicial de professores}

A primeira questão dentro desse eixo temático referia-se à importância que o docente atribui à inserção da temática ambiental nos cursos de formação de professores. Quase a totalidade dos docentes (22) considera importante e necessária essa inserção. Alguns demonstraram preocupação com o fato de ser algo obrigatório, "[...] porque se o docente não estiver preparado para fazer essa inserção, pode desconstruir alguma coisa, desinformar o aluno e formar um conceito equivocado [...]" (Coral). Por outro lado, outro docente considera que deve ser algo impositivo, autoritário, porque "[...] quando você deixa aberto, cada um trata; ninguém trata, é um ou outro [...]" (Tucano). A afirmação de outro docente complementa o assunto, ao dizer que "[...] tem que ter alguma normativa que oriente essa inserção, porque quando ela fica meio vaga, às vezes as pessoas põem algo meio vago também e isso não ajuda; e se for mal orientada é pior que nenhuma orientação, tem que ser bem orientada para que seja de fato feita" (Onça pintada).

Um dos docentes que tem experiência na inserção da temática ambiental na escola disse "[...] fica uma preocupação voltada só para a biologia, parece que meio ambiente é uma preocupação só de biólogo" (Bugio). Esse apontamento vem de encontro com alguns relatos encontrados na literatura, como o estudo de Souza, Kelecom e Araújo (2011), com discentes de licenciaturas da Universidade Federal Fluminense que consideraram os professores de Biologia e Geografia como os profissionais mais aptos para atuarem como educadores ambientais. Entretanto, analisando a formação inicial dos biólogos docentes do curso investigado nesta pesquisa, observa-se que a abordagem da temática ambiental para a maioria deles foi dentro de disciplinas de Ecologia, o que pode resultar em uma visão distorcida da complexidade ambiental. As afirmações de três docentes com graduação em Ciências Biológicas mostram o uso dos termos ambiental e ecologia como se fossem sinônimos:

[...] eu procurei dentro da minha disciplina onde uma questão ambiental podia estar relacionada para encaixar dentro daquela ementa... Não sou professor de Ecologia, mas tenho uma noção do assunto. (Coral)

Eu senti assim, onde eu vou pôr ecologia ou a parte ambiental no meu conteúdo? (Manacá) 
[...] no geral o ambiente está em tudo, o meio ambiente está em tudo, a ecologia está em tudo. (Bugio)

Assim sendo, fica claro que a formação inicial em um curso de Ciências Biológicas não garante a correta abordagem da temática ambiental. Os relatos de outros dois docentes da mesma área do conhecimento deixam isso ainda mais evidente: "Não é por ser biólogo que vai saber trabalhar com a questão ambiental. $O$ que me ajudou não foi só a formação, foi mais a experiência que eu tive em trabalhar com uma RPPN, em trabalhar com educação ambiental mesmo em projetos na escola" (Asplênio) e "[...] eu me considero como uma pessoa que ainda tem muita falha na percepção de educação ambiental, precisaria de uma formação ainda melhor até para poder discutir [...]" (Guapuruvu).

A maioria dos docentes (19) considera que a temática ambiental é trabalhada no curso de LCB da instituição, existindo "[...] um esforço muito grande por parte dos professores para trabalhar essa questão nas disciplinas" (Caranguejeira). Os outros cinco docentes disseram não saber responder a essa questão, porque o contato com o curso é pequeno.

Em relação ao número de disciplinas dentro do curso que deveria abordar a temática ambiental, nenhum docente considera que deveria ficar restrita a apenas uma. As opiniões se dividiram entre algumas disciplinas específicas (10 docentes) ou em todas as disciplinas (14 docentes), mas tendo em comum a ideia de que uma ou um grupo de disciplinas deve fazer uma abordagem mais específica e outras devem abordar de forma mais ampla.

\subsection{Práticas pedagógicas}

Dentro desse eixo temático, os docentes relataram a inserção (ou não) da temática ambiental nas suas aulas. Com isso, foi possível identificar a forma de inserção em 53 das 55 disciplinas oferecidas no curso de LCB em 2016 e organizar em três categorias: aquelas que não abordam (4); aquelas que abordam de forma pontual, esporádica (38); e aquelas em que é o foco principal da disciplina (11) (Quadro 4). Os docentes que mencionaram não abordar a temática justificaram a ausência pelo fato de ministrarem mais de uma disciplina no curso e inserirem a temática naquela disciplina que eles consideram ter maior relação.

Quadro 4 - Relatos sobre a abordagem da temática ambiental no curso

\begin{tabular}{|l|l|}
\hline $\begin{array}{c}\text { Inserção da } \\
\text { temática } \\
\text { ambiental }\end{array}$ & \multicolumn{1}{c|}{ EXCERTO } \\
\hline $\begin{array}{l}\text { Abordagem } \\
\text { esporádica }\end{array}$ & $\begin{array}{l}\text { "[...] existem alguns momentos que o foco ambiental vem à tona, mas é } \\
\text { esporádico, não está no escopo da disciplina, por exemplo, não de } \\
\text { maneira permanente, mas de maneira esporádica, em determinados } \\
\text { tópicos". (Bromélia) } \\
\text { "[...] eu faço uma abordagem em algum momento da disciplina e } \\
\text { obviamente não com a profundidade de um tema específico, não é uma } \\
\text { aula inteira sobre isso, mas não é só uma aula em que eu falo, é mais } \\
\text { de uma aula que eu falo, que a abordagem acontece". (Onça pintada) }\end{array}$ \\
\hline
\end{tabular}




\begin{tabular}{|l|l|}
\hline & $\begin{array}{l}\text { "[...] ela é abordada de forma bem simplista, não tem um } \\
\text { aprofundamento na discussão da temática da educação ambiental e } \\
\text { tudo mais. A gente discute algumas questões mais relacionadas com } \\
\text { exemplificação de alguns processos, de alguns fenômenos, é mais ou } \\
\text { menos por ẫ. (Coral) }\end{array}$ \\
\hline Foco principal & $\begin{array}{l}\text { "[..] para cada um dos tópicos eu sempre vou amarrando com o meio } \\
\text { ambiente. Se você for ver, quase todos os temas falam da questão } \\
\text { ambiental, não tem como dissociar". (Jacarandá) } \\
\text { "A disciplina é toda voltada para isso, trabalha todas as problemáticas } \\
\text { principais". (Caninana) }\end{array}$ \\
\hline
\end{tabular}

Comparando esses resultados com os obtidos em uma pesquisa anterior, que consistiu na análise documental da ambientalização curricular no projeto pedagógico do curso de LCB da instituição (COELHO-MIYAZAWA; FRENEDOZO; VIEIRA, 2017), verifica-se que das doze disciplinas que apresentaram indícios de ambientalização, cinco foram citadas como abordando a temática de forma eventual (História da Ciência e Tecnologia, Filosofia da Educação, Biotecnologia, Estatística Básica, Sistemática e Biogeografia); cinco como sendo o foco principal (Educação Ambiental e Sociedade; Química Ambiental; Conservação de Recursos Genéticos; Bioeconomia, Ecoeficiência e Sustentabilidade; Sistemas de Produção) e duas não foram mencionadas (Tópicos Avançados em Biologia 1, Tópicos Avançados em Biologia 6).

Essa mesma pesquisa revelou que das 65 disciplinas presentes na grade curricular, apenas oito não fazem nenhuma referência à temática ambiental, o que vem de encontro com o relato da coordenadora do curso de que "nenhum professor se manifestou de forma contrária à inserção da temática ambiental na sua disciplina na época em que a Pró-Reitoria de Ensino exigiu que fosse inserida no plano de ensino de todas as disciplinas". Em relação a isso, foi perguntado aos docentes se tiveram alguma dificuldade para inserir a dimensão ambiental na(s) sua(s) disciplina(s) quando a PRE solicitou essa alteração. Dos 24 docentes entrevistados, 8 não eram servidores do campus na época em que a solicitação foi feita e 2 já eram servidores, mas não ministravam aulas no curso. Dos 14 docentes entrevistados que participaram da reformulação do PPC, 3 disseram ter encontrado dificuldade para fazer a inserção e 11 disseram não ter encontrado nenhuma dificuldade, sendo que 6 desses disseram que já faziam essa abordagem.

O relato de um docente mostra que embora a inserção tenha sido exigida pela PRE, o resultado foi positivo porque o levou a pensar sobre o assunto: "Na verdade, eu até achei interessante porque algumas disciplinas eu não tinha tanto essa preocupação. Quando a PróReitoria trouxe essa obrigação, aí eu fui obrigado a pensar, foi difícil de inserir, mas foi algo novo, foi algo que eu não tinha parado para pensar antes" (Guapuruvu). Entretanto, pelo relato de muitos docentes, percebe-se que a inserção no projeto não foi realizada de forma reflexiva, por um trabalho conjunto dos docentes: "Às vezes me parece até que elas entraram como um adendo [...]" (Papagaio); "Não é algo extremamente confortável porque parece um pouco 'forçação' de barra, [...] fica uma coisa artificial”' (Figueira); “[...] tenho a impressão que é aquela coisa pontual para cumprir um regimento [...]" (Mico-Leão); "É duro, sai uma norma que a partir de hoje nas ementas dos cursos tem que ter a temática ambiental, aí você vai lá e põe uma frase a mais e não faz diferença" (Embaúba).

Como todos os docentes do curso foram entrevistados, ao considerar a totalidade das disciplinas oferecidas no curso, verificou-se que a complexidade da questão ambiental foi abordada, pois além da abordagem ecológica, houve apontamentos sobre a abordagem social "[...] uma disciplina que discute o funcionamento da sociedade e esse funcionamento 
relacionado com o meio ambiente" (Tucano), "[...] abordagem com a preocupação com a preservação, a questão da responsabilidade social, a questão da cidadania [...]" (Onça Pintada); cultural "Eu foquei mais nas questões de sustentabilidade, valorizando a questão cultural, para que eles entendessem essa relação do homem com o meio [...]" (Papagaio); política "[...] abordar a questão ambiental é mexer com algumas visões políticas, porque a política também está relacionada com esse viés" (Caranguejeira); e tecnológica "[...] quando eu falo de tecnologia, falo que a tecnologia que ajuda o humano é aquela que também traz um problema; a evolução da tecnologia vem para facilitar nossa vida, só que essa qualidade de vida muitas vezes se transforma em prejuízo ambiental" (Asplênio).

Pelo relato dos docentes, constatou-se que diferentes estratégias didáticas são utilizadas na abordagem da temática ambiental, com participação efetiva dos discentes no processo educativo, valorizando os conhecimentos e experiências que eles possuem. $\mathrm{O}$ Quadro 5 mostra exemplos de algumas disciplinas, com especificação do conteúdo e da técnica de ensino utilizada.

Quadro 5 - Abordagem da temática ambiental em disciplinas do curso

\begin{tabular}{|c|c|c|}
\hline Disciplina & Conteúdo & Técnica/Estratégia de ensino \\
\hline $\begin{array}{l}\text { Fundamentos da } \\
\text { Física }\end{array}$ & Aquecimento global & Videoaula e questionário \\
\hline $\begin{array}{l}\text { Fundamentos da } \\
\text { Matemática }\end{array}$ & $\begin{array}{l}\text { Crescimento } \\
\text { populacional exponencial }\end{array}$ & Resolução de problemas \\
\hline $\begin{array}{l}\text { Filosofia } \\
\text { Educação }\end{array}$ & $\begin{array}{l}\text { Ações humanas no } \\
\text { ambiente }\end{array}$ & Tempestade de ideias (brainstorming) \\
\hline $\begin{array}{l}\text { Geologia } \\
\text { Paleontologia }\end{array}$ & Chuva ácida & Aula prática no laboratório \\
\hline $\begin{array}{l}\text { Sistemas } \\
\text { Produção }\end{array}$ & $\begin{array}{l}\text { Alimentos orgânicos } \mathrm{e} \\
\text { transgênicos }\end{array}$ & Júri simulado \\
\hline $\begin{array}{l}\text { Química } \\
\text { Ambiental }\end{array}$ & $\begin{array}{l}\text { Desastres ambientais no } \\
\text { Brasil e no mundo }\end{array}$ & $\begin{array}{l}\text { Pesquisa de situações-problema } \\
\text { apresentação de seminários }\end{array}$ \\
\hline $\begin{array}{l}\text { Sociedade } \\
\text { Política }\end{array}$ & $\begin{array}{lll}\begin{array}{l}\text { Educação ambiental } \\
\text { sociedade }\end{array} & \mathrm{e} \\
\end{array}$ & Roda de conversa \\
\hline $\begin{array}{lr}\text { Tecnologias } & \text { da } \\
\text { Informação } & \text { no } \\
\text { Ensino de Ciências }\end{array}$ & Uso racional da água & $\begin{array}{l}\text { Desenvolvimento de objeto de } \\
\text { aprendizagem no ambiente de programação } \\
\text { Scratch }\end{array}$ \\
\hline
\end{tabular}

Nas disciplinas de Botânica I, Cordados, Ecologia I, Invertebrados I, Invertebrados II e Microbiologia, os docentes relataram articular o conhecimento específico disciplinar com a formação pedagógica, na maioria das vezes através da produção de jogos didáticos pelos discentes. A fala de um docente evidencia isso, ao dizer que quando solicita seminários para os discentes, pede que, além da teoria, eles incluam uma forma de como ensinar o conteúdo:

[...] o aluno faz a parte teórica e depois ele desenvolve o tema com os colegas de uma maneira diferenciada para fazer o resgate, a avaliação, se o pessoal entendeu ou não, na forma de uma dinâmica, de uma brincadeira, na forma de um quiz, alguma coisa nesse sentido, para eles treinarem essa questão de serem professores mesmo, de se apresentarem, de bolar novas técnicas [...] (Caranguejeira).

\subsection{Interdisciplinaridade e transversalidade}


Considerando o relato dos docentes, observou-se que a temática ambiental é abordada de forma transversal, permeando todo o curso, embora na maioria das disciplinas essa abordagem aconteça de forma esporádica. Isso ficou evidente nas afirmações "A carga de educação ambiental e disciplinas relacionadas ao meio ambiente realmente dá uma visão bem transversal" (Quaresmeira); "A questão ambiental acaba transpassando por todas as disciplinas, eu acho que ainda não existe uma reflexão muito grande sobre a inserção dela de maneira interdisciplinar, mas acho que já foi um começo" (Guapuruvu).

Alguns docentes mencionaram já ter desenvolvido trabalhos interdisciplinares com outros colegas envolvendo a temática ambiental, mas essas experiências "[...] são iniciativas de alguns professores, eu diria que a gente pratica quase zero, muito pouco, no curso mesmo os alunos não vivenciam a interdisciplinaridade" (Asplênio).

No início de 2016 houve reuniões na instituição, promovidas pela coordenadoria do curso, para discutir a interdisciplinaridade, sendo uma das possibilidades com a temática ambiental. A fala de uma docente que não é da área mostra a importância desses encontros:

Me convidaram para uma reunião da Biologia, eu não sou da área da Biologia, para que a gente pudesse discutir, por exemplo, o que eu poderia trabalhar de forma interdisciplinar. Eu achei legal eles me convidarem para essa reunião. Já é uma preocupação para se começar a trabalhar de uma forma interdisciplinar, foi uma reunião muito bacana (Caninana).

Um outro docente destaca que a discussão já existia, mas não de forma oficial, [...] na hora que a gente foi tentar oficializar isso, me chamou a atenção de que já era muito feito. De certa forma a gente já faz isso sim, de maneira não oficial, mas oficiosa, acho que acontece muito no dia a dia, que é o que eu acho mais bacana. Agora é questão de oficializar isso, de formatar. Tivemos uma discussão, vamos ver se a gente consegue pôr em prática agora (Bugio).

Como resultado das reuniões realizadas, quinze disciplinas desenvolveram ações consideradas interdisciplinares ao longo de 2016, com participação de oito docentes. A seguir apresenta-se um breve detalhamento dessas ações, por semestre do curso, com informações das entrevistas com os docentes:

$1^{\circ}$ semestre: pesquisa teórica, como um letramento inicial na área de pesquisa em Ciências Biológicas, nas disciplinas de Leitura, Produção e Interpretação de Textos e Metodologia do Trabalho Científico, em que os discentes podiam escolher o tema e alguns optaram pela área ambiental, e aula de campo em uma unidade de conservação municipal nas disciplinas de Fauna, Flora e Ambiente e História da Ciência e Tecnologia.

$2^{\circ}$ semestre: produção de artigos científicos relacionados a temas livres de Ciências Biológicas nas disciplinas de Diversidade Biológica e Redação Científica, em que oito grupos optaram por temas ambientais.

$4^{\circ}$ semestre: desenvolvimento de projetos da disciplina de Botânica II em parceria com outras disciplinas do mesmo semestre, com tema livre para cada grupo, sendo que cinco grupos optaram por tema ambiental envolvendo as disciplinas de Ecologia II, Invertebrados II e Tecnologias da Informação no Ensino de Ciências.

$7^{\circ}$ semestre: elaboração de projetos de educação ambiental voltados para o ensino médio para serem desenvolvidos nas escolas campo de estágio dentro das disciplinas de Educação Ambiental e Sociedade e Prática de Ensino de Biologia.

$8^{\circ}$ semestre: elaboração de atividades didáticas relacionadas a educação ambiental para serem aplicadas em escolas de ensino fundamental e médio dentro das disciplinas Conservação de Recursos Genéticos e Prática Pedagógica II e elaboração do Código 
de Ética do professor, incluindo a temática ambiental, nas disciplinas de Bioética e Prática Pedagógica II.

Com exceção da aula de campo, em que o trabalho integrativo dos docentes aconteceu no planejamento e execução, em todas as outras ações interdisciplinares o planejamento foi feito pelos docentes envolvidos, mas o desenvolvimento e avaliação ocorreram de forma isolada dentro de cada disciplina, ficando por conta dos discentes fazer a integração dos conhecimentos.

\subsection{Limites e potencialidades para inserção da temática ambiental}

Como fatores limitantes para inserção da temática ambiental nas disciplinas, foram apontados: (i) falta de tempo para trabalhar os conteúdos específicos e também a temática ambiental, considerando a carga horária da disciplina; (ii) falta de tempo para reunião com outros docentes e elaboração de trabalhos integrados; (iii) fuga do foco; (iv) ausência de projetos interdisciplinares; (v) falta de conhecimento técnico na área; (vi) número reduzido de aulas de campo; (vii) falta de materiais didáticos relacionando a temática ambiental com o conteúdo específico das disciplinas como histologia, bioquímica, cálculo e libras. O Quadro 6 traz relatos docentes referentes a alguns desses fatores.

Quadro 6 - Limites apontados pelos docentes para inserção da temática ambiental

\begin{tabular}{|l|l|}
\hline Limite & Excerto \\
\hline $\begin{array}{l}\text { Falta de tempo para incluir a } \\
\text { temática ambiental junto com } \\
\text { os conteúdos específicos }\end{array}$ & $\begin{array}{l}\text { "Unito preocupado pode dificultar se chama tempo, a gente fica } \\
\text { contextualização pode me tomar um tempo, até porque elas } \\
\text { geram discussão. Não é simplesmente você falar e encerrou } \\
\text { o assunto. Geralmente surge muita coisa em cima disso" } \\
\text { (Bugio). }\end{array}$ \\
\hline Fuga do foco & $\begin{array}{l}\text { "Às vezes a gente tem que esticar um pouco da relação de } \\
\text { um determinado tópico clássico daquela disciplina, } \\
\text { obrigatório, até você chegar lá em um tópico ambiental; } \\
\text { isso pode produzir um pouquinho de fuga do foco. Se você } \\
\text { se afasta muito do foco e volta, alguns alunos perdem a } \\
\text { sequência das coisas" (Bromélia). }\end{array}$ \\
\hline Falta de conhecimento técnico \\
& $\begin{array}{l}\text { "Eu me sinto à vontade para trabalhar a temática } \\
\text { ambiental, embora eu tenha uma visão a meu ver um pouco } \\
\text { limitada. Eu vejo a limitação da minha parte na questão } \\
\text { mais filosófica da educação ambiental" (Sibipiruna). }\end{array}$ \\
\hline
\end{tabular}

Já como potencialidades, os docentes indicaram tratar-se de uma temática fácil de inserir no conteúdo, "porque tudo tem uma conexão com meio ambiente" (Bromélia), "não é difícil a gente achar alguma coisa para encaixar dentro do conteúdo" (Bugio); tratar-se de uma temática atual, "A potencialidade é o momento que nós estamos vivendo, tanto eu como professora como os alunos, é uma coisa que está aí no dia a dia" (Mico-Leão), "O facilitador é a temática ambiental ser extremamente atual e isso facilita introduzir de alguma maneira, sem que isso soe estranho para aquele aluno que está fazendo aquela discussão, [...] sem que isso pareça fora de contexto para ele" e os discentes terem um conhecimento prévio sobre o assunto e demonstrarem interesse, permitindo uma maior discussão:

O potencial é grande, porque é um tema que todo mundo tem algum conhecimento prévio a respeito, então como a minha disciplina é no primeiro semestre, eu não 
consigo desenvolver altos debates sobre qualquer tema da área e as disciplinas do primeiro semestre são todas básicas, introdutórias, então esse é um tema que tem potencial na discussão (Figueira).

Eles manifestam muito mais interesse quando trabalho a temática ambiental, opinam mais e acho que isso motiva a argumentação, que é um ponto que eu trabalho quando é uma temática da área ambiental, eles se sentem, eles têm mais propriedade na hora de responder, eles gostam (Angico).

\section{Discussão}

Os resultados mostram que apesar de todos os docentes considerarem importante a inserção da temática ambiental na formação de professores, a maioria deles tem uma visão tradicional e conservadora de Educação Ambiental, indicando servir para sensibilização em relação à preservação ou conservação do ambiente, ou para mudança de comportamentos ambientalmente inadequados. Essas concepções têm, de acordo com Tozoni-Reis (2007), um fundo ingênuo e imobilista no primeiro caso, e disciplinatório e moralista, no segundo caso, sendo desprovidas de reflexões críticas, sem preocupação com os fundamentos científicos, o contexto sócio-econômico-cultural e o alinhamento político-ideológico (AMARAL, 2004).

Além disso, alguns docentes utilizaram o termo ambiental como sendo sinônimo de ecologia, indicando ainda mais uma visão reducionista e fragmentada da temática. Isso ocorre, em parte, em virtude de a formação inicial deles ter abordado essa temática focada na área biológica, sem uma percepção mais ampla do contexto. Por outro lado, há de se considerar que o debate ambiental no Brasil iniciou por volta de 1973, com viés conservacionista, comportamentalista, voltado para o ensino da Ecologia, em que "falar em ambiente era pensar em relações ecológicas descoladas da totalidade social, em um assunto técnico voltado para a resolução dos problemas ambientais" (LOUREIRO, 2006, p. 50) e se mantém dessa forma até os dias atuais na maioria das instituições brasileiras.

Ao contrário de pesquisas realizadas com outros cursos de licenciatura, em que a inserção da temática ambiental é ausente ou incipiente (ARAÚJO; OLIVEIRA, 2008; DINIZ; CHAGAS, 2014; FERRARO JÚNIOR, 2004; GOUVÊA, 2006; GUIMARÃES; INFORSATO, 2012; RODRIGUES, 2012; ROSA; ZANON, 2013; ROSALEM; BAROLLI, 2010; SOUZA; KELECOM; ARAÚJO, 2011; VILELA; FARIAS, 2013); no estudo realizado com o curso de LCB, observa-se que ela esteve presente, na prática, em quase todas as disciplinas ofertadas em 2016, de acordo com o relato dos docentes. Inicialmente, a temática ambiental foi inserida nos planos de ensino das disciplinas por uma exigência da PRE. Na época, não houve espaço de discussão para o corpo docente definir como se daria o processo, mas todos concordaram em inserir a temática ambiental nas suas disciplinas, segundo relatou a coordenadora do curso. Embora a inserção apenas para cumprir a legislação não seja o melhor caminho, representou um grande avanço para que a preocupação com a questão ambiental fosse incorporada à estrutura curricular e às práticas do curso.

A temática ambiental é abordada de forma eventual na maioria das disciplinas, restrita a alguns momentos no decorrer do semestre e, como foco principal, em um número menor de disciplinas, sendo, assim, considerada pelo corpo docente como uma abordagem transversal. Nesse sentido, vale analisar o que aponta Carvalho (2005, p. 61) de que isso tanto pode significar "estar em todo lugar quanto, ao mesmo tempo, não pertencer a nenhum dos lugares já estabelecidos na estrutura curricular que organiza o ensino", concluindo que, no curso de LCB, a temática está presente em quase todos os lugares. É importante constatar a presença da temática ambiental no curso, mas somente isso não é o suficiente para garantir uma adequada formação dos discentes. O modo como se dá essa inserção também é imprescindível. 
Ao considerar o conjunto de disciplinas que constituem o curso, verificou-se que a complexidade da questão ambiental é abordada, mas de forma fragmentada, em que cada disciplina destaca aspectos diferentes da temática ambiental, cabendo aos discentes fazer a integração dos conteúdos entre si e as relações destes com questões tecnológicas, sociais, econômicas, culturais e políticas. Esse resultado já era esperado, considerando as concepções de meio ambiente e EA apresentadas pelos docentes. Se a temática ambiental for trabalhada sob um viés conservacionista, pode gerar práticas para a manutenção da ideologia dominante que impeçam um entendimento mais crítico e contextualizado, desconsiderando toda a complexidade das questões ambientais (JULIANI; SANTOS; GARCIA; REZENDE-FILHO, 2014). Para superar o senso comum, em relação ao conceito de meio ambiente e educação ambiental, é necessário um aprofundamento fílosófico e epistemológico dos conceitos e das práticas em EA (TAGLIEBER; GUERRA, 2002). Considerando os apontamentos de Henriques, Trajber, Mello, Lipai e Chamusca (2007), defende-se a necessidade de reformular os conhecimentos dos docentes e adotar medidas institucionais que favoreçam relações dialógicas e interdisciplinares.

Os conteúdos e técnicas de ensino apontadas pelos docentes (Quadro 5) indicam que algumas disciplinas oferecem oportunidades aos discentes de análise e reflexão sobre as causas e consequências dos problemas ambientais. Além disso, na abordagem ambiental existe interação entre o conhecimento específico e a formação pedagógica, visto que disciplinas como Filosofia da Educação, Prática Ensino de Biologia e Prática Pedagógica II abordam a temática, e disciplinas específicas como Botânica, Ecologia, Invertebrados, Educação Ambiental e Sociedade e Conservação de Recursos Genéticos abordam como a temática ambiental pode ser trabalhada no ensino fundamental e médio.

As reuniões promovidas pela coordenadoria do curso de LCB representaram um ponto de partida para a implementação de ações interdisciplinares, tornando possível o diálogo e motivando o interesse de oito docentes, mas como não houve uma formação específica sobre como deveriam ser desenvolvidas e nem uma reestruturação curricular, as disciplinas continuaram a ser ministradas de forma compartimentada, fornecendo subsídios aos discentes para unirem os conhecimentos das diferentes áreas na execução de uma mesma atividade. Festozo e Tozoni-Reis (2015) encontraram resultados semelhantes, analisando a inserção da educação ambiental em um curso de pedagogia desenvolvido por meio de um projeto interdisciplinar, visto que constataram que o trabalho de integração das disciplinas ficava a cargo dos alunos que tinham que realizar uma interdisciplinaridade que não se efetivava ao longo do curso nas disciplinas. O trabalho, dessa forma, tem seu mérito, visto que permite um enriquecimento da formação discente com contribuições de cada disciplina para uma compreensão mais abrangente da temática ambiental, mas dificilmente gera mudanças nos procedimentos e modos de produção do conhecimento que se mantenham a longo prazo. Seguindo as definições dadas por Pires (1998), as ações desenvolvidas no curso de LCB se encaixam melhor dentro do conceito de multidisciplinaridade, existindo uma justaposição de disciplinas que tratam de temas comuns sob sua própria ótica, articulando, algumas vezes, técnicas de ensino e procedimentos de avaliação. Para a mesma autora, na interdisciplinaridade a integração deve ir muito além da troca de informação sobre objetivos, conteúdos, procedimentos e compatibilização de bibliografia, devendo ocorrer uma integração dos caminhos epistemológicos, da metodologia e da organização do ensino.

Romper a fragmentação do conhecimento e inserir a temática ambiental através de uma abordagem interdisciplinar representa um grande desafio, com a superação de várias barreiras. Para isso, é necessário disponibilizar carga horária e criar um espaço permanente de diálogo no curso, relacionado com a temática ambiental, em que os docentes sejam participantes ativos em sua inserção, considerando a sua prática, os conhecimentos didático- 
pedagógicos e os conhecimentos específicos numa perspectiva integradora. Não é preciso que todas as disciplinas sejam modificadas em profundidade, é possível continuar com uma abordagem eventual nas disciplinas ministradas por docentes que não tenham formação específica na área e maior ênfase nas disciplinas ministradas por docentes especialistas; mas é necessário o diálogo entre eles sobre o que e como será trabalhado, para que o conjunto das mudanças no currículo leve a uma "transformação dos educandos pela construção de valores sociais, conhecimentos, habilidades, atitudes e competências, conforme prevê o Art. $1^{\circ}$ da Política Nacional de Educação Ambiental - PNEA" (KITZMANN; MOTA, 2017, p. 184). "Afinal, nem sempre é necessário mudar o que se faz, mas, sim, mudar como se faz" (FREIRE; FIGUEIREDO; GUIMARÃES, 2016, p. 122).

Uma maior integração entre as disciplinas irá valorizar as relações dos conteúdos entre si e as relações destes com a complexidade ambiental, contribuindo para a constituição de uma visão de mundo mais ampla dos futuros professores de Ciências e Biologia, assim como uma atuação crítica na sociedade em que se insere. Deve-se buscar um caminho que ajude na superação das formas fragmentadas do pensar e agir, organizadas sob o paradigma da interdisciplinaridade (TOZONI-REIS, 2001), construindo o conhecimento "para a prática da interrelação, da interdisciplinaridade, conexão e interação entre áreas diferentes" (LIMA; ARRUDA; ANDRADE; PISSETTI, 2017, p. 144).

A incorporação da temática ambiental nos currículos é um processo demorado e depende da capacitação dos docentes e de que eles aprendam a trabalhar em equipe e a socializar resultados (THOMAZ; CAMARGO, 2007). É de fundamental importância a oferta de educação continuada para os docentes, para reflexão de suas concepções e práticas de EA, porque muitas vezes não estão preparados para correlacionar o conteúdo específico da disciplina que ministram às questões ambientais.

Não é possível pensar a formação do professor independente da profissão docente, nem a educação continuada independente da formação inicial, daí a importância de conhecer os docentes do curso. É preciso o contínuo entrelaçamento da formação do docente com o cotidiano da instituição, todas as suas responsabilidades e o seu trabalho, que não apenas o ambiental e que haja um compromisso institucional, flexibilizando o tempo do professor para que ele possa participar (AMARAL, 2004). Deve-se ter em conta a formação de uma identidade pessoal e profissional, dialogando com a vida do docente, "suas experiências, seus projetos de vida, suas condições de existência, suas expectativas sociais, sob pena de se transformar em mais uma tarefa entre tantas que tornam o cotidiano do professor um sem fim de compromissos" (CARVALHO, 2005, p. 62). Deve-se não apenas ampliar os conhecimentos dos docentes, mas também torná-los agentes multiplicadores que contribuam na formação de professores mais críticos, dinâmicos, que incorporem a temática ambiental nas suas aulas e lutem por uma sociedade mais justa e ambientalmente saudável (UNTALER; BAROLLI, 2010).

\section{Considerações finais}

Os resultados obtidos indicam que a maioria dos docentes pesquisados apresentam uma visão conservacionista e comportamentalista de EA, mais voltada para os aspectos naturais e mudanças de atitudes. Isso ocorre em virtude de não terem recebido ao longo da sua formação pessoal, acadêmica e profissional, conhecimentos dentro da perspectiva crítica.

Os docentes relataram que inserem a temática ambiental nas práticas das suas disciplinas, mas na maioria delas de forma esporádica, quando surgem oportunidades de relacionar com os conteúdos específicos. Não houve diálogo entre os docentes para organizar o modo de inserção, ficando sob a responsabilidade de cada um definir como isso se daria 
na(s) sua(s) disciplina(s). Essa inserção passou a ser feita na maioria das disciplinas depois que a PRE fez a exigência para cumprir uma obrigatoriedade legal, o que representou um grande avanço para que a temática ambiental passasse a estar presente nas atividades acadêmicas do curso.

Entretanto, como a obrigatoriedade veio sem estar acompanhada de um espaço de diálogo, ainda se observa falhas no processo que precisam ser aprimoradas, assim como há a necessidade de superar os limites apontados pelos docentes, como a falta de tempo, fuga do foco, ausência de projetos interdisciplinares, falta de conhecimento técnico e falta de materiais didáticos.

É de fundamental importância que a instituição se comprometa com o aperfeiçoamento desse processo, oferecendo educação continuada aos docentes em direção a uma visão complexa da realidade e que haja um espaço para o constante diálogo entre eles, buscando a articulação dos conhecimentos e o trabalho interdisciplinar; respeitando a autonomia de cada um.

Uma análise mais abrangente e aprofundada sobre a inserção da temática ambiental no curso de LCB será possível com a continuidade da pesquisa, analisando a visão dos discentes e egressos, bem como verificando se os professores formados pelo curso estão trabalhando a educação ambiental nas escolas.

Pensar em uma formação inicial de professores que contemple a inserção da temática ambiental de forma crítica, emancipatória, problematizadora, reflexiva e interdisciplinar requer obrigatoriamente um compromisso institucional e um corpo docente qualificado para atuar nesse sentido.

\section{Referências}

ARAÚJO, M. I. O. A universidade e a formação de professores para a educação ambiental. Revista Brasileira de Educação Ambiental, Brasília, DF, n. 0, p. 71-78, 2004.

ARAÚJO, M. L. F.; OLIVEIRA, M. M. Formação de professores de biologia e educação ambiental: contribuições, deficiências e estratégias. Revista Eletrônica do Mestrado em Educação Ambiental, Rio Grande, v. 20, p. 256-273, 2008.

AMARAL, I. A. Programas e ações de formação docente em educação ambiental. In: TAGLIEBER, J. E.; GUERRA, A. F. S. (org.). Pesquisas em educação ambiental: pensamentos e reflexões de pesquisadores em educação ambiental. Pelotas: Ed. Universitária, 2004. p. 145-167.

BARDIN, L. L'Analyse de contenu. Paris: Presses Universitaires de France, 1977.

BARDIN, L. Análise de conteúdo. São Paulo: Edições 70, 2011.

BILERT, V. S. S. O desafio da ambientalização na formação universitária. Revista Eletrônica em Gestão, Educação e Tecnologia Ambiental, Santa Maria, v. 18, n. 3, p.1154-1161, set-dez. 2014.

BRASIL. Lei $\mathrm{n}^{\circ}$ 9.795, de 27 de abril de 1999. Dispõe sobre a educação ambiental, institui a Política Nacional de Educação Ambiental e dá outras providências. Diário Oficial da União, Brasília, DF, 28 abr. 1999.

BRASIL. Ministério da Educação. Instrumento de avaliação de cursos de graduação: presencial e a distância. Brasília, DF: Inep, 2015. Disponível em: http://download.inep.gov.br/educacao_superior/avaliacao_cursos_graduacao/instrumentos/2012/instru mento_com_alteracoes_maio_12.pdf. Acesso em: 15 out. 2019. 
CARVALHO, I. C. M. A invenção do sujeito ecológico: identidade e subjetividade na formação dos educadores ambientais. In: SATO, M.; CARVALHO, I. C. M. (org.) Educação ambiental: pesquisas e desafios. Porto Alegre: Artmed, 2005. p. 53-65.

COELHO-MIYAZAWA, G. C. M.; FRENEDOZO, R. C.; VIEIRA, R. M. Ambientalização curricular no projeto pedagógico de um curso de Ciências Biológicas. Indagatio Didactica, Aveiro, v. 9, n. 4, p. 407-425, 2017.

CORTES JUNIOR, L. P.; FERNANDEZ, C. A educação ambiental na formação de professores de química: estudo diagnóstico e representações sociais. Química Nova, São Paulo, v. 39, n. 6, p. 748$756,2016$.

DINIZ, J. C. A.; CHAGAS, F. A. O. A educação ambiental na formação inicial de professores de física do IFG e de professores de ciências biológicas e de física da UFG. Cadernos de Educação, Tecnologia e Sociedade, Inhumas, v. 5, p. 221-234, 2014.

DI TULLIO, A.; OLIVEIRA, H. T. Trajetórias da construção da identidade de professoras do ensino básico como educadoras ambientais. Pesquisa em Educação Ambiental, Ribeirão Preto, v. 12, n. 1, p. 42-57, 2017.

FERRARO JÚNIOR, L. A. A universidade e a formação do educador ambiental: uma breve reflexão sobre as experiências da Universidade Estadual de Feira de Santana - UEFS. Revista Brasileira de Educação Ambiental, São Paulo, n. 1, p. 116-119, 2004.

FESTOZO, M. B.; TOZONI-REIS, M. F. C. Educação ambiental e participação na formação de professores. ambientalMENTE sustentable, Coruña, v. 2, n. 20, p. 613-636, 2015.

FRAZÃO, J. O.; SILVA, J. M.; CASTRO, C. S. S. Percepção ambiental de alunos e professores na preservação das tartarugas marinhas na praia de Pipa - RN. Revista Eletrônica do Mestrado em Educação Ambiental, Rio Grande, v. 24, p. 156-172, 2010.

FREIRE, L.; FIGUEIREDO, J.; GUIMARÃES, M. O papel dos professores/educadores ambientais e seus espaços de formação. Qual é a educação ambiental que nos emancipa? Pesquisa em Educação Ambiental, Ribeirão Preto, v. 11, n. 2, p. 117-125, 2016.

GOUVÊA, G. R. R. Rumos da formação de professores para a educação ambiental. Educar em Revista, Curitiba, n. 27, p. 163-179, 2006.

GUERRA, A. F. S. et al. A temática ambiental e a sustentabilidade nos cursos de graduação da Univali: caminhos para a ambientalização curricular na universidade. Revista Eletrônica do Mestrado em Educação Ambiental, Rio Grande, v. especial, p. 121-134, maio 2014.

GUIMARÃES, M. A formação de educadores ambientais. 2. ed. Campinas: Papirus, 2005.

GUIMARÃES, M.; QUEIROZ, E. D.; PLÁCIDO, P. O. Reflexões sobre a pesquisa na formação de professores/educadores ambientais. Pesquisa em Educação Ambiental, Ribeirão Preto, v. 9, n. 1, p. 110-119, 2014.

GUIMARÃES, S. S. M.; INFORSATO, E. C. Educação ambiental e formação de professores de biologia no município de Piracicaba/SP. Revista Eletrônica do Mestrado em Educação Ambiental, Rio Grande, v. 25, p. 315-329, 2010. 
GUIMARÃES, S. S. M.; INFORSATO, E. C. A percepção do professor de biologia e a sua formação: a educação ambiental em questão. Ciência e Educação, Bauru, v. 18, n. 3, p. 737-754, 2012.

HENRIQUES, R.; TRAJBER, R.; MELLO, S.; LIPAI, E. M.; CHAMUSCA, A. Educação ambiental: aprendizes de sustentabilidade. Brasília, DF: Secad: MEC, 2007.

JACOBI, P. R. Educação ambiental: o desafio da construção de um pensamento crítico, complexo e reflexivo. Educação e Pesquisa, São Paulo, v. 31, n. 2, p. 233-250, 2005.

JULIANI, S. F.; SANTOS, L. M.; GARCIA, E.; REZENDE-FILHO, L. A. C. Inserção da educação ambiental na formação inicial docente: levantamento de publicações. Revista de la Facultad de Ciencia y Tecnologia, Bogotá, v. 2014, p. 1555-1562, 2014.

KITZMANN, D.; MOTA, J. C. Ambientalização sistêmica nas instituições de educação superior. In: FIGUEIREDO, M. L. et al. (org.) Educação para ambientalização curricular: diálogos necessários. São José: Icep, 2017. p. 181-194.

LIMA, L. C.; ARRUDA, M. P.; ANDRADE, I. C. F.; PISSETTI, S. L. C. Para reforma e ambientalização do pensamento: primeiras aproximações. In: FIGUEIREDO, M. L. et al. (Org.) Educação para ambientalização curricular: diálogos necessários. São José: ICEP, 2017. p. 135-149.

LIPAI, E. M.; LAYRARGUES, P. P.; PEDRO, V. V. Educação ambiental na escola: tá na lei. In: MELLO, S. S.; TRAJBER, R. (coord.) Vamos cuidar do Brasil: conceitos e práticas em educação ambiental na escola. Brasília, DF: MEC: Unesco, 2007. p. 23-32.

LOPES, T. M.; ZANCUL, M. C. S. A inclusão de temas ambientais nos cursos de ciências biológicas de universidades públicas paulistas. Revista Eletrônica do Mestrado em Educação Ambiental, Rio Grande, v. 29, p. 1-16, 2012.

LOUREIRO, C. F. B. Aspectos políticos e pedagógicos da educação ambiental no Brasil: um convite à reflexão. Sinais Sociais, Rio de Janeiro, v. 1, n. 2, p. 44-83, 2006.

MODESTO, M. A.; ARAÚJO, M. I. Por uma (trans)formação ambiental: reflexões sobre ambientalização curricular e interdisciplinaridade nos cursos de pedagogia de universidades sergipanas. Ambiente e Educação, Rio Grande, v. 20, n. 2, p. 45-64, 2015.

MOITA NETO, J. M.; SANTOS, K. A perspectiva ambiental no curso de licenciatura em física da UFPI: reflexões sobre o atual Projeto Político Pedagógico. Revista Brasileira de Ensino de Física, São Paulo, v. 33, n. 3, p. 1-4, 2011.

MORALES, A. G. Diversidade de olhares e sentidos na formação do profissional em educação ambiental. Revista Eletrônica do Mestrado em Educação Ambiental, Rio Grande, v. especial, p. 156$171,2010$.

OLIVEIRA, M. G.; CARVALHO, L. M. Políticas públicas de formação de professores e de educação ambiental: possíveis articulações? Revista Contemporânea de Educação, Rio de Janeiro, v. 7, n. 14, p. 252-275, 2012.

PAVESI. A. Uma abordagem prática da ambientalização curricular: a experiência da escola de engenharia de São Carlos (EESC-USP). In: LEME, P. C. S.; PAVESI, A.; ALBA, D.; G., M. J. D.; GONZÁLEZ, M. S. (org.). Visões e experiências ibero-americanas de sustentabilidade nas universidades. Madrid: Alambra, 2012. v. 1. p. 151-157. 
PIRES, M. F. C. Multidisciplinaridade, interdisciplinaridade e transdisciplinaridade no ensino. Interface: Comunicação, Saúde, Educação, Botucatu, v. 2, n. 2, p. 173-182, 1998.

PITANGA, A. F.; NEPOMUCENO, A. L. O; ARAUJO, M. I O. Entendimentos e práticas de ensino de professores universitários em educação ambiental. Revista Eletrônica do Mestrado em Educação Ambiental, Rio Grande, v. 34, n. 1, p. 270-289, 2017.

RODRIGUES, C. A ambientalização dos currículos de Educação Física no ensino superior. Motriz, Rio Claro, v. 18, n. 3, p.557-570, 2012.

RODRIGUES, J. N.; OLIVEIRA, A. L.; QUEIROZ, E. D. Universidade e formação de educadores ambientais críticos. Educação: Teoria e Prática, Rio Claro, v. 23, n. 42, p. 90-105, 2013.

ROLOFF, F. B.; MARQUES, C. A. Questões ambientais na voz dos formadores de professores de química em disciplinas de cunho ambiental. Química Nova, São Paulo, v. 37, n. 3, p. 549-555, 2014.

ROSA, A. M. A.; ZANON, A. M. Visão da educação ambiental na Universidade Federal de Mato Grosso do Sul a partir do diagnóstico entre acadêmicos de cursos de formação de professores. In: ENCONTRO PESQUISA EM EDUCAÇÃO AMBIENTAL, 7., 2013, Rio Claro. Anais [...]. Rio Claro: Unesp, 2013. p. 4-18.

ROSALEM, B. M.; BAROLLI, E. Ambientalização curricular na formação inicial de professores: o curso de pedagogia da FE-Unicamp. Revista Brasileira de Educação Ambiental, São Paulo, v. 5, n. 1, p. 26-36, 2010.

SANTOS, V. M. N.; JACOBI, P. R. Formação de professores e cidadania: projetos escolares no estudo do ambiente. Educação e Pesquisa, São Paulo, v. 37, n. 2, p. 263-278, 2011.

SAUVÉ, L. Educação ambiental: possibilidades e limitações. Educação e Pesquisa, São Paulo, v. 31, n. 2, p. 317-322, 2005a.

SAUVÉ, L. Uma cartografia das correntes em educação ambiental. In: SATO, M.; CARVALHO, I. C. M. (org.). Educação ambiental: pesquisas e desafios. Porto Alegre: Artmed, 2005b. p. 17-45.

SILVA, L. F.; TEIXEIRA, E. S. A educação para a sustentabilidade: representações de educação ambiental em docentes de formação de professores. Revista de Ciências Humanas, Frederico Westphalen, v. 16, n. 27, p. 7-21, 2015.

SOUZA, V. M.; KELECOM, A.; ARAÚJO, J. A educação ambiental: conceitos e abordagens pelos alunos de licenciatura da Universidade Federal Fluminense. Uniara, Araraquara, v. 14, n. 1, p. 52-67, 2011.

SOUZA, V. M. Para o mercado ou para a cidadania? A educação ambiental nas instituições públicas de ensino superior no Brasil. Revista Brasileira de Educação, Rio de Janeiro, v. 21, n. 64, p. 121-142, 2016.

TAGLIEBER, J. E.; GUERRA, A. F. S. A dimensão ambiental na educação e as representações docentes. In: ENCONTRO PERSPECTIVAS DO ENSINO DE BIOLOGIA, 8., 2002, São Paulo. Coletânea [...]. São Paulo: Feusp/Edusp, 2002. p. 1-5.

TEIXEIRA, C.; TORALES, M. A. A questão ambiental e a formação de professores para a educação básica: um olhar sobre as licenciaturas. Educar em Revista, Curitiba, v. 30, n. especial 3, p. 127-144, 2014. 
THOMAZ; C. E.; CAMARGO, D. M. P. Educação ambiental no ensino superior: múltiplos olhares. Revista Eletrônica do Mestrado em Educação Ambiental, Rio Grande, v. 18, p. 303-318, 2007.

TOZONI-REIS, M. F. C. Educação ambiental: referências teóricas no ensino superior. Interface: Comunicação, Saúde, Educação, Botucatu, v. 5, n. 9, p. 33-50, 2001.

TOZONI-REIS, M. F. C. Fundamentos teóricos para uma pedagogia crítica da Educação Ambiental: algumas contribuições. In: REUNIÃO DA ASSOCIAÇÃO NACIONAL DE PÓS-GRADUAÇÃO E PESQUISA EM EDUCAÇÃO, 30., 2007, Caxambu. Anais [...]. Caxambú, 2007. p. 1-16.

TOZONI-REIS, M. F. C.; CAMPOS, L. M. L. Educação ambiental escolar, formação humana e formação de professores: articulações necessárias. Educar em Revista, Curitiba, v. 30, n. especial 3, p. 145-162, 2014.

TOZONI-REIS, M. F. C.; CAMPOS, L. M. L. A formação de professores para a educação ambiental escolar. Comunicações, Piracicaba, v. 22, n. 2, p. 13-33, 2015.

TRISTÃO, M. Educação ambiental na sociedade do conhecimento. In: RUSCHEINSKY, A. (org.). Educação ambiental: abordagens múltiplas. Porto Alegre: Artmed, 2002. p. 169-183.

UNTALER, L. O.; BAROLLI, E. Educação ambiental e a formação inicial de professores: o que dizem as pesquisas? Olhares e Trilhas, Uberlândia, v. 12, n. 2, p. 19-26, 2010.

VILELA, B. T. S; FARIAS, C. R. O. Ambientalização curricular no ensino superior: o caso do curso de licenciatura plena em Ciências Biológicas da Universidade Federal Rural de Pernambuco (UFRPE). In: ENCONTRO NACIONAL DE PESQUISA EM EDUCAÇÃO EM CIÊNCIAS, 9., 2013, Águas de Lindóia. Anais [...]. Águas de Lindóia, 2013. p. 1-8. 